\title{
Abundance of Conepatus chinga (Carnivora, Mephitidae) and other medium-sized mammals in grasslands of southern Brazil
}

\author{
Carlos B. Kasper ${ }^{1}$, Vinícius A. G. Bastazini², José B. G. Soares ${ }^{3} \&$ Thales R. O. de Freitas ${ }^{4}$
} 1. Programa de Pós-Graduação em Biologia Animal, Instituto de Biociências, Universidade Federal do Rio Grande do Sul, Av. Bento Gonçalves, $9500,90510-970$ Porto Alegre, RS, Brasil.
(cbkasper@yahoo.com.br)
2. Programa de Pós-Graduação em Ecologia, Laboratório de Ecologia Quantitativa, Universidade Federal do Rio Grande do Sul, Av. Bento Gonçalves, 9500, Prédio 43411, sala 205, $90510-970$
Porto Alegre, RS, Brasil. (bastazini@hotmail.com)
3. Instituto Pró-Pampa, Nossa Senhora das Graças 294, 96330-000 Arroio Grande, RS, Brasil. (jbsoares.ag@ hotmail.com)
4. Laboratório de Citogenética e Evolução, Departamento de Genética, Universidade Federal do Rio Grande do Sul, Av. Bento Gonçalves, 9500, Prédio 43323, sala 101, 90510-970 Porto Alegre,
RS, Brasil. (thales.freitas@ufrgs.br)

\begin{abstract}
Between January 2007 and December 2010, the abundance of medium-sized mammals was studied, with special focus on the Molina's hog-nosed skunk, Conepatus chinga (Molina, 1782), at four locations in southern Brazil. In this study, transect line methodology was used to obtain data for Distance Analyses. Transects were traveled by car at night, searching with spotlights along the edges of secondary roads in agricultural landscapes. Along 1,811 km, we obtained 620 observations of 20 mammal species. The most common species was the exotic European hare, Lepus europaeus (Pallas, 1778); the highest abundance estimated for South America was observed in one of the study areas, where its density was estimated as 32 individuals $/ \mathrm{km}^{2}$. Carnivores were the most commonly recorded mammals, represented by 10 species and comprising $51 \%$ of all observations. Molina's hog-nosed skunk occurred in all study areas, but occurred in sufficient numbers to obtain density estimates in only two of the areas. We estimated 1.4 to 3.8 individuals $/ \mathrm{km}^{2}$, in the first density estimate made by the transect method for a member of Conepatus in the Neotropics. These values are similar to those estimated for North American species of Mephitidae. In Brazil, C. chinga is apparently more abundant in the Pampa biome than in the grasslands of the Atlantic Forest. For two other carnivores, Lycalopex gymnocercus (Fisher, 1814) and Cerdocyon thous (Linnaeus, 1766), we estimated preliminary densities that were similar to those previously cited for different regions.
\end{abstract}

KEYWORDS. Density, Pampa, transect lines, sympatric species.

RESUMO. Abundância de Conepatus chinga (Carnivora, Mephitidae) e outros mamíferos de médio porte nos campo do sul do Brasil. Entre janeiro de 2007 e dezembro de 2010 a abundância de mamíferos de médio porte foi estudada, com especial ênfase no zorrilho Conepatus chinga (Molina, 1782) em quatro locais no sul do Brasil. Neste estudo, foi utilizada a metodologia de transectos lineares de forma a obter dados para análises de densidade com uso do software Distance. Os transectos foram percorridos de carro, à noite, procurando por animais na periferia de estradas secundárias, com o uso de holofotes de longo alcance. Em $1.811 \mathrm{~km}$ percorridos, foram obtidos 620 registros de 20 espécies de mamíferos. A espécie mais comum foi a lebre européia Lepus europaeus (Pallas, 1778), para a qual, em uma das áreas estudadas, foi obtida a maior estimativa de abundância já registrada para a América do Sul, com uma densidade estimada de 32 indivíduos por km². Carnivora foi a ordem mais comumente registrada, representada por 10 espécies que, juntas, compreenderam $51 \%$ de todas as visualizações. O zorrilho ocorreu em todas as áreas estudadas, embora só tenha sido registrado em número suficiente para a obtenção de estimativas de densidade em duas destas áreas. A densidade do zorrilho foi estimada em 1,4 a 3,8 indivíduos por $\mathrm{km}^{2}$, sendo esta a primeira estimativa por transectos lineares do gênero Conepatus na região Neotropical. Estes valores são similares aos observados para mefitídeos norte-americanos. No Brasil, C. chinga é aparentemente mais abundante no Pampa do que nos campos de altitude da Mata Atlântica. Para outras duas espécies, Lycalopex gymnocercus (Fisher, 1814) e Cerdocyon thous (Linnaeus, 1766), foram feitas estimativas preliminares de densidade que apontaram valores semelhantes aos de outras regiões de ocorrência das espécies.

PALAVRAS-CHAVE. Densidade, Pampa, transecções lineares, espécies simpátricas.

Species abundance is a central aspect in population ecology. Abundance can be affected by several ecological factors, including food availability, competition and predation. Two basic and different measures of abundance can be estimated by sampling animal populations: density and abundance. Absolute density refers to a quantitative measure of numbers of individuals per area, which can be converted into an estimate of population size. Abundance refers to population densities relative to a unit other than area, such as records per hour surveyed or observations per kilometer sampled (CASSEY, 1999). Indices are generally based on the assumption that the sample represents a constant but unknown proportion of the population. These indices are easily obtained and useful for comparing different sites or trends with repeated sampling over time (GESE, 2001). Chiarello (1999), for example, used abundance indices to evaluate the impact of fragmentation on mammal assemblages in the Atlantic Forest. Yet, in general, there is a lack of knowledge of this aspect for most Neotropical mammals, even for the most common species.

The Neotropical mammal fauna is mostly composed of small species, such as rodents, marsupials and bats. Among medium-sized mammals $(>1 \mathrm{~kg})$, most of the species are arboreal (e.g., primates), which together with small mammals represent nearly $88 \%$ of all mammal diversity in South America (FonseCA et al., 1999). However, the Neotropical region has extensive areas of open habitat, often resembling the landscape of African savannas. In contrast to African mammals, the majority of South American mammals are inconspicuous, with a relatively small number of medium- to largesized species. Most of them have secretive habits and are difficult to observe.

Even relatively common species have been poorly 
studied, and abundance estimates are few, especially based on transect lines. In Brazil, this method has been used in aerial counts of marsh deer Blastocerus dichotomus (Illiger, 1815) (e.g., Schaller \& Vasconcelos, 1978; Pinder, 1997; Mourão et al., 2000; Andriolo, 2005), and boat counts for cetaceans (e.g., CREMER \& SimÕEsLopes, 2008; Flach et al., 2008). Transect lines on the ground are used basically to estimate densities of primates (e.g., Peres, 1997; GonZÁlez-Solís et al., 2001; Santana et al., 2008). Carnivores are inherently less abundant than herbivores (EISENBERG, 1999), and usually hard to see, making it difficult to apply these methods. Perhaps because of this, studies conducted in Brazil to estimate the density of carnivores with transect lines such as that of Rocha et al. (2008), with a fox species Lycalopex vetulus (Lund, 1842) in the Cerrado Biome, are rare. On the other hand, some poorly known species can be easily observed in their habitats, for example, the Molina's hog-nosed skunk, Conepatus chinga (Molina, 1782). In southern Brazil, C. chinga is one of the most common medium-sized mammals occurring in open areas, but despite this, studies of its density or relative abundance are still lacking.

In this study, we aimed to estimate the density of C. chinga, as well as the relative abundances of other medium-sized mammals, at two sites in the Pampas grasslands and two sites in the grasslands of the Atlantic Forest, comparing patterns of the composition of assemblages of medium-sized mammals.

\section{MATERIALS AND METHODS}

Study Area. This study was conducted in four areas in southern Brazil located in two basic biotic formations, the grasslands of the Atlantic Forest and the Pampas grasslands. In northeastern of state of Rio Grande do Sul and in southern of state of Santa Catarina, grasslands occur in Atlantic Forest highlands (800 $1200 \mathrm{~m}$ ). This formation is associated with fragments of Atlantic Forest with a conspicuous presence of the Brazilian Pine (Araucaria angustifolia (Bert.) O. Ktze). Figure 1 shows the open formations of southern Brazil and the locations of the areas studied. The first area (A), studied between July and December 2007, is located in Santa Catarina in the municipality of Campo Belo do Sul $\left(27^{\circ} 58^{\prime} \mathrm{S}, 50^{\circ} 49^{\prime} \mathrm{W}\right)$. Transects were located in a large pine forest (Pinus spp.) cultivated for timber. This area includes several native fragments of Atlantic Forest along streams and springs. Originally, until the 1950s, the area was occupied by grasslands used for cattle ranching, which were then converted to pine forest. The second area (B), studied between July 2007 and March 2008, is located in Rio Grande do Sul, in the municipality of Bom Jesus ( $\left.28^{\circ} 19^{\prime} \mathrm{S}, 50^{\circ} 43^{\prime} \mathrm{W}\right)$. Transects were located on a cattle ranch, comprising large areas of native grasslands with several patches of Atlantic Forest with Araucaria angustifolia. The third area (C), located in southeastern
Rio Grande do Sul in the municipality of Arroio Grande $\left(33^{\circ} 19^{\prime} \mathrm{S}, 53^{\circ} 54^{\prime} \mathrm{W}\right)$, near the border with Uruguay, was studied between February 2008 and April 2009. The area is near the coastal plain, in the drainage basin of the Lagoa Mirim. It is composed of a mosaic of open grasslands used for cattle ranching, extensive areas of irrigated ricefields, marshes, and some forest patches of native and exotic trees (mainly Eucalyptus spp.). The last area (D), located in southwestern Rio Grande do Sul in the municipality of Alegrete $\left(30^{\circ} 05^{\prime} \mathrm{S}, 55^{\circ} 30^{\prime} \mathrm{W}\right)$, also near the border with Uruguay, was studied between July 2009 and December 2010. The landscape is composed of grasslands and some forest patches that occur mainly along watercourses. Transects were established through livestock ranches.

Data collection and analyses. The study was based on line-transect methodology (Burnham et al., 1980; Buckland et al., 1993). For this purpose, we established transects along secondary and farm roads: three at each site, ranging from 3 to $8 \mathrm{~km}$ (mean $=4.8$ $\mathrm{km}$ ) long. Transects were sampled during three to five consecutive nights, each month or once per season. Each transect was repeated twice each night, with a minimum interval of one hour between each round trip. As the main goal of this study was to obtain density estimates of $C$. chinga, it was not viable to invest in areas with few animals, since a minimum number of records are needed to perform estimates using the Distance Program. Therefore, 24 samples in each transect during six months were established as the minimum sampling effort at each site. Because we used existing roads, the transects were not linear and they usually followed the smoothest relief. Sampling was carried out at night between 8:00 $\mathrm{pm}$ and 03:00 am by car, driven at a constant speed of $10-15 \mathrm{~km} / \mathrm{h}$; with one observer using a spotlight, scanning both sides of the road in search of mediumsized mammals, especially $C$. chinga (Cervantes et al., 2002). When a mammal was located, the driver stopped the car in a perpendicular position, or approximately 20 $\mathrm{m}$ distant, if the animal was close to or on the road. If the animal was clearly identified, the observer measured the perpendicular distance to the location of the first visual contact with the animal, using a measuring tape. In cases of doubtful species identity (canids seen at long distances, for example), the sighting was discarded.

The perpendicular distances were measured with the maximum possible precision, based on visual characteristics of each site, such as shrubs, rocks, fences or anything that could help the observer to identify the first location of visual contact. Data collected were analyzed using the software Distance (THомas et al., 2010). Perpendicular sighting data were modeled according to the Akaike Information Criterion (AIC). We present point density estimates with a confidence interval of $95 \%$, standard error, coefficient of variation, and the probability of detection.

Density was calculated for all species with 60 


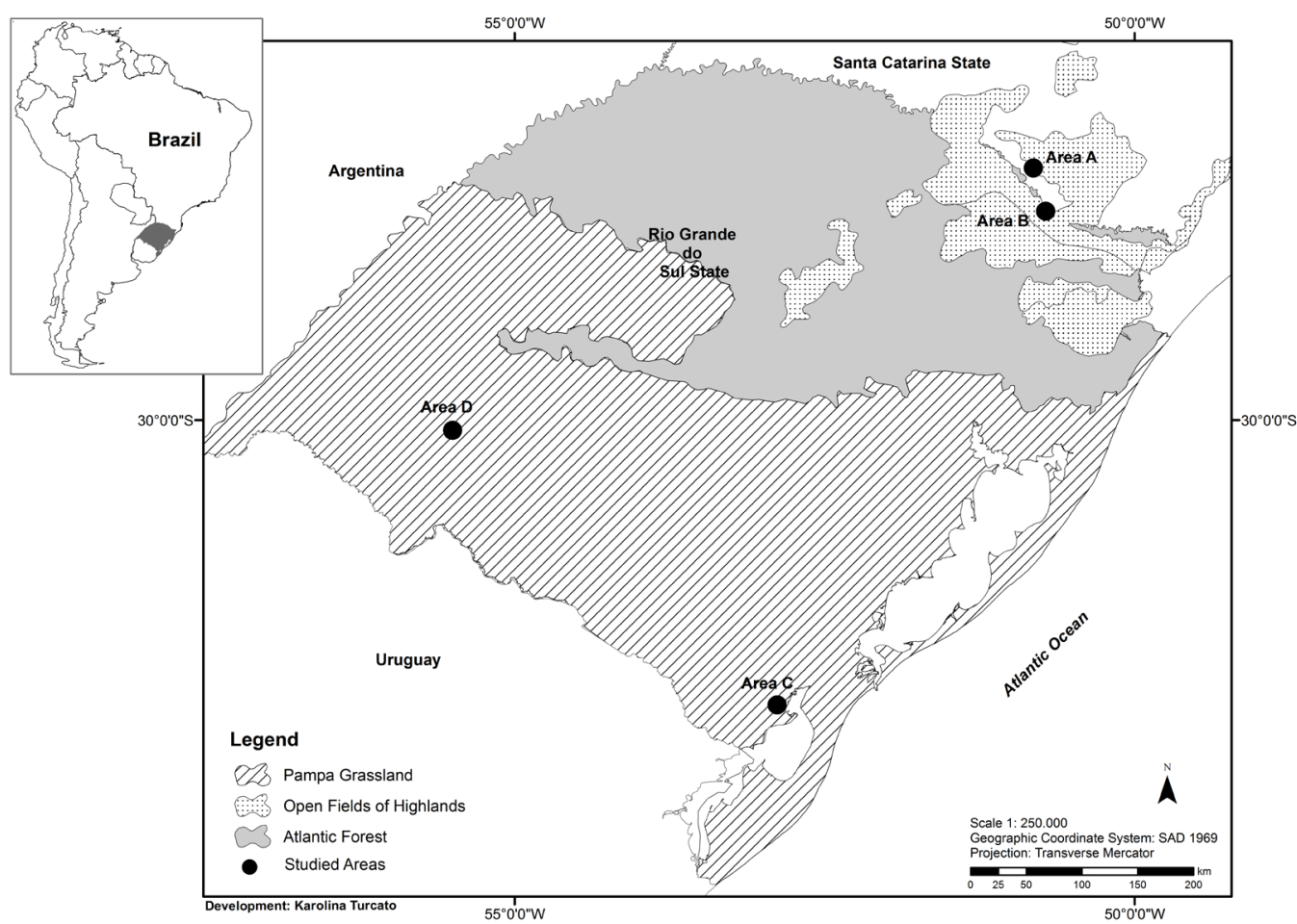

Fig. 1. Locations of areas used to estimate abundances of medium-sized mammals, at Pampa and grasslands of the Atlantic Forest, in southern Brazil.

(or more) sightings, which is considered suitable for robust estimates (BuCKLAND et al., 1993). For all species with about 30 sightings, we estimated "preliminary densities". These preliminary estimates represent an approximation, derived from data sets that did not allow robust analyses because of the small number of records. For other species, we present only abundance indices, based on the number of sightings divided by the distance traveled.

\section{RESULTS}

General results. In the entire study, $1,811 \mathrm{~km}$ of transects were sampled, and 620 sightings of 20 mammal species were recorded. The most common species was the European hare Lepus europaeus (Pallas, 1778), which comprised $41 \%$ of the total observations. Carnivores were the most common order recorded, represented by 10 species and $51 \%$ of all observations.

On Gateados farm, $223 \mathrm{~km}$ were sampled with 65 records of eight species, i.e., one sighting for every $3.66 \mathrm{~km}$ of transect (Tab. I). Cerdocyon thous (Linnaeus, 1766) was the most common species recorded, with $48 \%$ of the observations (12.1 sightings for each 100 $\mathrm{km}$ of transect), followed by Mazama gouazoubira (Fisher, 1814) with 29\% (8.52 sightings $/ 100 \mathrm{~km}$ ), and L. europaeus with $15 \%$ (4.48 sightings $/ 100 \mathrm{~km}$ ). Other species, including $C$. chinga, were recorded only once.

At Bom Jesus, $276 \mathrm{~km}$ were sampled, along which we obtained 66 records of nine species, representing one sighting for every $4.18 \mathrm{~km}$ of transect (Tab. I). In this area, Lycalopex gymnocercus (Fisher, 1814) was the most abundant species, with $57 \%$ of the observations (13.77 sightings/100 km), followed by L. europaeus with $18 \%$ (4.35 sightings $/ 100 \mathrm{~km}$ ). Two other species showed intermediate abundances, $C$. thous and Procyon cancrivorus (Cuvier, 1789), each with 8\% (1.81 sightings $/ 100 \mathrm{~km}$ ) of the observations. Again, C. chinga was recorded only once.

At Arroio Grande, 1,052 km were sampled, with 205 records of nine species, representing one sighting for every $5.13 \mathrm{~km}$ of transect (Tab. I). The most common species in this area was C. chinga, with $30 \%$ of the observations $(5.80$ sightings $/ 100 \mathrm{~km})$, followed by $L$. europaeus (18\%; 3.52 sightings/100 km), C. thous (16\%; 3.14 sightings $/ 100 \mathrm{~km})$ and L. gymnocercus $(15 \% ; 2.95$ sightings $/ 100 \mathrm{~km}$ ) with relatively high abundances. In this area, Leopardus geoffroyi (d'Orbigny \& Gervais, 1844), P. cancrivorus and Myocastor coypus Kerr, 1792 showed intermediate abundances.

At Alegrete, $260 \mathrm{~km}$ were sampled, along which 284 records of 11 species were obtained, representing one sighting for each $0.91 \mathrm{~km}$ of transect (Tab. I). Lepus europaeus was recorded in very high frequency, representing $68 \%$ of the observations $(73.85$ sightings $/ 100 \mathrm{~km}$ ), followed by $C$. chinga in high abundance, with $25 \%$ of the records (26.92 sightings/ $/ 100$ $\mathrm{km})$. All other species showed low abundances, with the exception of $C$. thous and L. gymnocercus, which had intermediate abundances (1.54 and 3.08 sightings/100 $\mathrm{km}$ respectively).

Density estimates. We generated two density 
estimates for four species: C. chinga, C. thous, $L$. gymnocercus and L. europaeus. We were able to make a robust estimate of density for C. chinga in two areas, and for L. europaeus in only one. Two other species had only a small number of records, compelling us to consider our estimates as preliminary with respect to two of the study areas.

Conepatus chinga was the most common carnivore species in two areas, Arroio Grande and Alegrete, with densities ranging from $1.1(0.7-1.2)$ to $3.8(2.9-5.1)$ individuals $/ \mathrm{km}^{2}$ (Tab. II). The coefficients of variation of these analyses were $16.5 \%$ and $14.4 \%$, respectively.

Cerdocyon thous and L. gymnocercus showed similarly low estimated densities (Tab. II). For C. thous the estimates ranged from $0.4(0.2-0.6)$ to $0.9(0.6-1.3)$ individuals $/ \mathrm{km}^{2}$ at Arroio Grande and Gateados farm, respectively. For L. gymnocercus the estimates ranged from $0.2(0.15-0.35)$ to $1.1(0.7-1.6)$ individuals $/ \mathrm{km}^{2}$ in Arroio Grande and Bom Jesus, respectively. However, these estimates are preliminary, with relatively high coefficients of variation, from $21.4 \%$ to $24.1 \%$.

European hare densities varied drastically between the study areas. Because few animals were observed in two of the areas, it was not possible to estimate their density. Yet in two other areas, hares were present in intermediate and very high abundances (Tab. II). For
Arroio Grande, we made only a preliminary estimate because of a small number of records, of $0.3(0.2-0.4)$ individual $/ \mathrm{km}^{2}$ with a $21.7 \%$ coefficient of variation. On the other hand, a robust analysis was possible for Alegrete, for which we estimated a density of 31.9 (23.7 - 42.9) individuals $/ \mathrm{km}^{2}$, with a $15.1 \%$ coefficient of variation.

\section{DISCUSSION}

Relative abundance. Each area showed a singular assemblage, varying between one and four "exclusive species". This term is in quotes because the failure to record a species does not imply that it is absent in the environment. In fact, the nine-banded armadillo Dasypus novemcinctus Linnaeus, 1758 and the pampas fox L. gymnocercus are very common in southern Brazil, and certainly occur in all the study areas; as is the grison Galictis cuja (Molina, 1782), although it always occurred in low abundance (C. B. Kasper, unpubl. data). The four study areas are strongly impacted by humans. The main impacts are caused by agricultural activities, especially livestock at Bom Jesus, Arroio Grande and Alegrete. Gateados farm is used for timber production, and therefore has the most distinct fauna. In this area the crab-eating fox $C$. thous was the most abundant

Tab. I. Species abundance (sightings per $100 \mathrm{~km}$ of transects) at four areas in southern Brasil: Gateados farm, Campo Belo do Sul, SC (area A), Bom Jesus, RS (area B), Arroio Grande, RS (area C) and Alegrete, RS (area D).

\begin{tabular}{|c|c|c|c|c|}
\hline \multirow[b]{2}{*}{ Species } & \multicolumn{4}{|c|}{ Study areas } \\
\hline & $\begin{array}{c}\text { Gateados } \\
\text { farm }\end{array}$ & $\begin{array}{l}\text { Bom } \\
\text { Jesus }\end{array}$ & $\begin{array}{l}\text { Arroio } \\
\text { Grande }\end{array}$ & Alegrete \\
\hline \multicolumn{5}{|l|}{ Didelphimorphia } \\
\hline Didelphis albiventris Lund, 1840 & & & 0.29 & 0.77 \\
\hline \multicolumn{5}{|l|}{ Cingulata } \\
\hline Cabassous totoay (Desmarest, 1804) & & 0.36 & & \\
\hline Dasypus hibridus (Desmarest, 1804) & & & & 0.77 \\
\hline Dasypus novemcinctus Linnaeus, 1758 & & & & 0.77 \\
\hline \multicolumn{5}{|l|}{ Carnivora } \\
\hline Leopardus colocolo (Molina, 1782) & & & & 0.38 \\
\hline Leopardus geoffroyi (d’Orbigny \& Gervais, 1844) & & & 1.52 & 0.38 \\
\hline Leopardus pardalis (Linnaeus, 1758) & 0.45 & & & \\
\hline Puma concolor (Linnaeus, 1771) & 0.45 & & & \\
\hline Cerdocyon thous (Linnaeus, 1766) & 12.11 & 1.81 & 3.14 & 1.54 \\
\hline Lycalopex gymnocercus (Fisher, 1814) & & 13.77 & 2.95 & 3.08 \\
\hline Lontra longicaudis (Olfers, 1818) & & & 0.10 & \\
\hline Galictis cuja (Molina, 1782) & & & & 0.38 \\
\hline Conepatus chinga (Molina, 1782) & 0.45 & 0.36 & 5.80 & 26.92 \\
\hline Procyon cancrivorus (Cuvier, 1798) & & 1.81 & 0.86 & \\
\hline \multicolumn{5}{|l|}{ Cetartiodactyla } \\
\hline Pecari tajacu (Linnaeus, 1758) & & 0.36 & & \\
\hline Tayassu pecari (Link, 1795) & 0.45 & & & \\
\hline Mazama gouazoubira (Fisher, 1814) & 8.52 & 0.72 & & \\
\hline \multicolumn{5}{|l|}{ Rodentia } \\
\hline Hydrochoerus hydrochaeris Brisson, 1762 & 0.45 & & & \\
\hline Myocastor coypus Kerr, 1792 & & 0.36 & 1.33 & 0.38 \\
\hline \multicolumn{5}{|l|}{ Lagomorpha } \\
\hline Lepus europaeus (Pallas, 1778) & 4.48 & 4.35 & 3.52 & 73.85 \\
\hline Total & 27.35 & 23.91 & 19.49 & 109.23 \\
\hline
\end{tabular}


Tab. II. Density estimates of the most common median sized mammals in grasslands of southern Brazil [D, density estimate (individuals $\left./ \mathrm{km}^{2}\right)$; CI, $95 \%$ confidence interval (individuals $\left./ \mathrm{km}^{2}\right)$; SE, standard error; CV, coefficient of variation (\%); DP, detection probability (\%); *, preliminary estimates].

\begin{tabular}{|c|c|c|c|c|c|c|}
\hline Species & Area & $\mathrm{D}$ & $\mathrm{CI}$ & SE & $\mathrm{CV}$ & $\mathrm{DP}$ \\
\hline \multirow{2}{*}{ Conepatus chinga } & Arroio Grande & 1.1 & $0.7-1.2$ & 0.18 & 16.5 & 43.9 \\
\hline & Alegrete & 3.8 & $2.9-5.1$ & 0.55 & 14.4 & 22.1 \\
\hline \multirow{2}{*}{ Cerdocyon thous } & Gateados & $0.9^{*}$ & $0.6-1.3$ & 0.19 & 21.7 & 27.9 \\
\hline & Arroio Grande & $0.4^{*}$ & $0.2-0.6$ & 0.09 & 24.1 & 47.1 \\
\hline \multirow{2}{*}{ Lycalopex gymnocercus } & Bom Jesus & $1.1 *$ & $0.7-1.6$ & 0.23 & 21.4 & 25.7 \\
\hline & Arroio Grande & $0.2^{*}$ & $0.15-0.35$ & 0.05 & 22.2 & 41.4 \\
\hline \multirow{2}{*}{ Lepus europaeus } & Arroio Grande & $0.3^{*}$ & $0.2-0.4$ & 0.06 & 21.7 & 19.6 \\
\hline & Alegrete & 31.9 & $23.7-42.9$ & 4.81 & 15.1 & 38.3 \\
\hline
\end{tabular}

species, with 31 records, followed by the gray brocket deer Mazama gouazoubira, which is remarkable. In this case, the abundance of the gray brocket deer is probably associated with an absence of hunting. Paradoxically, this exotic pine-forest environment harbors a large number of species, including some locally endangered species (FonTANA et al., 2003), such as the white-lipped peccary Tayassu peccary (Link, 1795), collared peccary Pecary tajacu (Linnaeus, 1758), ocelot Leopardus pardalis (Linnaeus, 1758), and mountain lion Puma concolor (Linnaeus, 1771). It is likely that these species can persist only because of the preservation of native forest in the ravines. However, it seems clear that the mosaic formed by patches of native and exotic forests, and the absence of hunting are beneficial to several species, especially larger species that require extensive areas to maintain their populations.

Bom Jesus, located only $80 \mathrm{~km}$ from area A, is very different in terms of soil and landscape usage. The area is used for cattle ranching, and the landscape includes several forest patches in the middle of open grasslands, on the hilltops, and bordered by the Atlantic Forest in the ravines. Therefore, some forest species are present in the patches and ravines, although the assemblage of mammals is characteristic of open areas. The most abundant species in this area was the Pampas fox, followed by the European hare, two species typical of open environments. It is interesting to note the numerical dominance of L. gymnocercus over C. thous, which many studies have found to be the dominant species (Di BitetTi et al., 2009; Faria-Correa et al., 2009). This is not always necessarily true, and this relationship is probably more complex than it appears.

In Arroio Grande (Area C), a greater field effort was employed, using transects concomitantly with telemetry studies of C. chinga (KASPER et al., 2012). In this area, $C$. chinga was the most abundant species, with 61 records (one sighting for every $17.2 \mathrm{~km}$ of transect), nearly twice that of the next most abundant species, $L$. europaeus, with 37 records. The area showed the lowest encounter indices of all four areas, with 19 sightings every $100 \mathrm{~km}$. This probably reflects the high level of disturbance in the area, which is used intensely for agriculture, especially rice farming and cattle ranching. This is the only study area that had vehicular traffic on the roads used as transects, which certainly affected detectability, because some species or individuals may avoid areas adjacent to busy roads. Aside from detectability, density itself can be affected, as suggested by the observation of several road-killed individuals.

Alegrete showed the highest encounter indices, with 109 records every $100 \mathrm{~km}$, a lot more than in the other areas. This number can be explained by the enormous local abundance of the European hare, which alone represented 74 encounters per $100 \mathrm{~km}$ traveled. Yet even after this exotic species was excluded from the analysis, Alegrete still showed the highest abundance in terms of mammals, because we also found the highest abundance of $C$. chinga, nearly five times higher than in Arroio Grande, with 27 encounters every $100 \mathrm{~km}$. The two sympatric canids were found at intermediate levels, with a predominance of $L$. gymnocercus. A possible explanation for the large number of animals in this area is landscape use. Pampas grasslands are used primarily for cattle ranching, an activity that began in the 1800 s and has not changed much since then. Cattle ranching is so intimately associated with this region that several investigators have argued that the landscape is modulated by this activity, and that the maintenance of biodiversity is dependent on the regime of disturbances such as grazing and burning to improve pasture (OvERBECK et al., 2009). Obviously, there is a threshold for the intensity of these disturbances, leading to decreases in biodiversity and the loss of ecological processes (PILlar et al., 2009). However, the region can be considered relatively well preserved, although humans have made use of practically all the available space.

Densities. There is little published information about the abundance of skunks, and no data for the southern species. The South American species exhibit parapatric distributions, in contrast to North American skunks. Therefore, in South America each skunk species shares its habitat with carnivores of other families, but not with other mephitids, which in theory reduces the 
potential for competition among them. The abundance of $C$. chinga should be higher than those of species living in sympatry and sharing resources, as in the case of northern skunks. However, the densities estimated in our study are similar to those commonly observed for Mephitis mephitis (Schreber, 1776) (WADE-Sмith \& Verts, 1982), a larger animal than C. chinga. On the other hand, densities were much lower than for Spilogale putorius (Linnaeus, 1758), found in numbers of 8.8 to 40 individuals $/ \mathrm{km}^{2}$ (KINLAW, 1995), although they have only 1/3 the body mass of C. chinga. In Arroio Grande, the estimated density of C. ching $a$ is similar to densities of the most common of three sympatric species studied in Mexico (Cervantes et al., 2002).

The only density estimate available for Conepatus in South America was derived from telemetry studies, and was $0.68-1.66$ individuals $/ \mathrm{km}^{2}$ in croplands and protected areas respectively (CASTILlo et al., 2011). These authors used spotlight surveys to estimate density, but did not succeed because of the small number of sightings. It is very difficult to compare results derived by different methods, as each technique has different sources of bias. Density estimates based on telemetry data are only valid if no other animal lives within the total area used by the marked animals (GESE, 2001). Individuals of $C$. chinga show considerable overlap in their home ranges, even among individuals of the same sex (REPUCCI et al., 2009; CASTILlo et al., 2011; KASPER et al., 2012), making it nearly impossible to mark all the animals in a given area. In a similar study, for example, KASPER et al. (2012) could not use this method of analysis because several non-marked individuals were sharing the areas of the monitored animals. However, CASTILLO et al. (2011) did not mention the possibility that their analyses could have produced underestimates, so we will assume that their numbers are valid. In this case, our estimates are higher than those in Argentina, despite the wide variability observed. This is interesting because Brazilian skunks are larger than the specimens from Argentina (KASPER et al., 2012), which in theory implies that they should have lower densities. We suggest that these differences may be related to the availability of food, which generally correlates with precipitation. In southern Brazil, the annual mean precipitation is around $1200-1600$ mm (CABRERA \& WilLINK, 1980), while in Argentina it is around $500-1000 \mathrm{~mm}$. Therefore, it is possible that southern Brazil has greater resource availability, allowing for higher densities. Another reference available for South American skunks is Cofré \& MARquet (1999), who reported densities of 5 individuals $/ \mathrm{km}^{2}$ for $C$. ching $a$ and 89 individuals $/ \mathrm{km}^{2}$ for Conepatus humboldtii Gray, 1837. However, these estimates were included among those for several other species, and it is not clear how the authors determined the values. Therefore we do not consider this information sufficiently reliable for comparison with our study.

The observed abundance of $C$. ching $a$ in our study areas varied widely, from very low levels, where we could not estimate the density, to areas with relatively high densities. One possibility is the difference in availability of certain resources, especially insect larvae, which is the main item in this species' diet (Medina et al., 2009; Peters et al., 2011). This hypothesis should be tested in the future, to better understand the processes affecting its abundance. However, in Arroio Grande the abundance of $C$. chinga is probably strongly affected by human disturbances, including road mortality and hunting. In this area, seven of 18 marked animals were killed as a consequence of human activities in a period of 12 months, representing an almost $40 \%$ decrease of the known population (Kasper et al., 2012). The low levels of abundance in the Atlantic Forest highlands may be a particular characteristic of this population.

The density of Lycalopex gymnocercus was estimated first by CRESPO (1971), who found 1.04 individuals $/ \mathrm{km}^{2}$ in the Argentine Pampas, very similar to our estimate in the highlands of the Atlantic Forest. In the Paraguayan Chaco, Brooks (1992) found a density of 0.64 fox groups $/ \mathrm{km}^{2}$, while the highest density estimate is from the Bolivian Chaco, with 1.8 individuals $/ \mathrm{km}^{2}$ (Ayala \& Noss, 2000). These estimates are similar to ours, despite the very different habitats. The values are also similar to a report for Lycalopex vetulus in "campo sujo" of the Brazilian Cerrado (1.21 individuals $/ \mathrm{km}^{2}$ ) (Rocha et al., 2008), although estimates for pasture fields at the same location were very different, with up to 4.28 individuals $/ \mathrm{km}^{2}$ (Rocha et al., 2008). However, we cannot directly compare these two species, because $L$. vetulus has a diet specialized in termites and other insects, whereas the diet of L. gymnocercus is more generalized (CheIDA \& SAntos, 2010). The several density estimates for different species of the genus Pseudalopex compiled by Hoffmann \& Sillero-Zubiri (2004) indicate densities of 0.5 to 2.0 individuals $/ \mathrm{km}^{2}$ as a common pattern for Neotropical foxes.

The numbers of $L$. gymnocercus in our study were probably influenced by hunting, as we found low abundances in the areas with high hunting pressure such as at Arroio Grande and especially at Alegrete. Arroio Grande is more densely occupied, which generates more conflict with carnivores in general. At Alegrete, which has large cattle and sheep ranches, there is an effective and illegal control of canids (C. thous and $L$. gymnocercus), which supposedly serves to reduce the loss of lambs to predation. At Bom Jesus, which is used exclusively for cattle, hunting pressure is lower than at Arroio Grande and Alegrete, allowing more Pampas foxes to survive.

The crab-eating fox (C. thous) is the most common carnivore in southern Brazil, although not always the most abundant. This species is more associated with forested areas and gallery forests, but also occupies open areas, agricultural landscapes, highly fragmented environments, and even suburban areas. The densities 
estimated in our study are similar to that estimated for a dry forest in Santa Cruz (Bolivia) of 1 individual/ $\mathrm{km}^{2}$ (MAFFeI \& TABER, 2003). Cerdocyon thous occurs in all areas of southern Brazil, while L. gymnocercus is restricted to open areas of the Pampas grasslands and the open grasslands of the Atlantic Forest. These species are very similar in size, and recent studies have revealed extensive overlap in their feeding habitats. The coexistence of these foxes was the subject of some studies (e.g., Di BitetTi et al., 2009; Faria-CorrêA et al., 2009; ABREU et al., 2010) that have suggested that niche overlap is attenuated by differences in activity period or by their differential use of microhabitats to forage. We believe that these two species affect each other's abundance reciprocally. How this occurs, at what intensity, and what affects this relationship are still-unanswered questions. However, this relationship is probably not linear, with $C$. thous always being the dominant species, since in some areas $L$. gymnocercus shows similar or even higher abundances.

The European hare Lepus europaeus is an introduced species that is thriving in southern Brazil, Uruguay and Argentina. We estimated two levels of density for southern Brazil, at two different abundance levels. In two other areas in the highlands of the Atlantic Forest, its abundance was very low and was not calculated. However, this hare has probably become one of the most common medium-sized mammals in southern Brazil, especially in the Pampas grasslands. This abundance of hares is high even when compared to their original habitat in Poland, with densities of $10-$ 28 individuals $/ \mathrm{km}^{2}$ (PANEK, 2009), and the Netherlands, where the density is around 25 individuals $/ \mathrm{km}^{2}$ (CHAPMAN $\&$ Fuux, 1990). Although this hare can reach $200-300$ individuals $/ \mathrm{km}^{2}$ in some cases, its density is usually low, even in non-native habitats such as New Zealand, with densities around 10-20 individuals (CHAPMAN \& FLuX, 1990). In South America, density estimates range from $2.6-5.1 \mathrm{hares} / \mathrm{km}^{2}$ (АмAYA, 1979) to $9.5( \pm 4.5)-12.6( \pm$ 1.9) (PIA et al., 2003), both from Argentina. Therefore, our estimate is the highest reported to date for South America, and amplifies our understanding of this exotic species' potential to occupy southern Brazil.

Acknowledgements. We are grateful to Mr. Zeca Soares for his hospitable support for our study on his property in Arroio Grande; to Ms. Graça Tirelli for permission and support of our work on her property in Alegrete; to Alice Hirschmann, Marina Foresti Picolli, Maurício Tavares, Manoel Rodrigues, Gitana Nunes, Fábio Dias Mazim, Eduardo Eizirik, and many others who collaborated in field work and in the laboratory for the success of this project. Special thanks to CNPq for a Doctoral Scholarship.

\section{REFERENCES}

Abreu, M. S. L.; Wieliczko, A. R.; Mesquita, A. \& Vieira, E. M. 2010. Consumo de pequenos mamíferos por canídeos simpátricos do sul do Brasil: sobreposição de nichos e seleção de presas. Neotropical Biology and Conservation 5(1):16-23.

Amaya, J. N. 1979. The European Hare in Argentina. Comunicación
Tecnica no. 20 - 1979 - Area de Recursos Naturales: Fauna. San Carlos de Bariloche, Secretaría de Agricultura, Ganadería, Pesca y Alimentación, Instituto Nacional de Tecnología Agropecuaria, Estación Experimental Agropecuaria S. C. de Bariloche. 3p.

Andriolo, A.; Piovezan, U.; Costa, M. J. R. P.; Laake, J. \& Duarte, J. M. B. 2005. Aerial Line Transect Survey to Estimate Abundance of Marsh Deer (Blastocerus dichotomus) (Illiger, 1815). Brazilian Archives of Biology and Technology 48(5):807-814.

Ayala, J. \& Noss, A. 2000. Censo por transectas en El Chaco Boliviano: limitaciones biológicas y sociales de la metodología. In: Cabrera, E.; Mercolli, C. \& Resquin, R. eds. Manejo de Fauna Silvestre en Amazonia y Latinoamérica. Asunción, Ricor Grafic S. A. p. 29-36.

BRooks, D. 1992. Notes on group size, density, and habitat association of the Pampas fox (Dusicyon gymnocercus) in the Paraguayan Chaco. Mammalia 56(2):314-316.

Buckland, S. T.; Anderson, D. R.; Burnham, K. P. \& Laake. J. L. 1993. Distance Sampling. Estimating Abundance of Biological Populations. London, Chapman \& Hall. 432p.

Burnham, K. P.; Anderson, D. R. \& LaAke, J. L. 1980. Estimation of density from line transect sampling of biological populations. Wildlife Monographs 72:1-202.

Cabrera, A. L. \& Willink, A. 1980. Biogeografía de América Latina. 2ed. Washington, Programa Regional de Desarrollo Científico y Tecnológico, Organización de los Estados Americanos (Monografía 13, serie biologia). 117p.

CASSEY, P. 1999. Estimating animal abundance by distance sampling techniques. Wellington, Conservation Advisory Science Notes No. 237. 14p.

Castillo, D. F.; Lucherini, M.; Vidal, E. M. L.; Manfredi, C. \& Casanave, E. B. 2011. Spatial organization of Molina's hognosed skunk (Conepatus chinga) in two landscapes of the Pampas grassland of Argentina. Canadian Journal of Zoology 89(3):229-238.

Cervantes, F. A.; Loredo, J. \& Vargas, J. 2002. Abundance of sympatric skunks (Mustelidae: Carnivora) in Oaxaca, Mexico. Journal of Tropical Biology 18(3):463-469.

Chapman, J. A. \& Flux, J. E. C. 1990. Rabbits, Hares and Pikas: Status Survey and Conservation Action Plan. Gland, International Union for the Conservation of Nature and Natural Resources. $177 \mathrm{p}$.

Cheida, C. C. \& Santos, L. B. 2010. Ordem Carnivora. In: Reis, N. R.; Peracchi, A. L.; Fregonezi, M. N. \& Rossaneis, B. K. eds. Mamíferos do Brasil: Guia de Identificação. Londrina, Technical Books, p.463-492.

Chiarello, A. G. 1999. Effects of fragmentation of the Atlantic forest on mammal communities in southeastern Brazil. Biological Conservation 89(1):71-82.

Cofré, H. \& Marquet, P.A. 1999. Conservation status, rarity and geographic priorities for conservation of Chilean mammals: an assessment. Biological Conservation 88: 53-68.

Cremer, M. J. \& Simões-Lopes, P. C. 2008. Distribution, abundance and density estimates of franciscanas, Pontoporia blainvillei (Cetacea: Pontoporiidae), in Babitonga bay, southern Brazil. Revista Brasileira de Zoologia 25(3):397-402.

Crespo, J. A. 1971. Ecología del zorro gris Dusicyon gymnocercus antiquus (Ameghino) en la provincia de La Pampa. Revista del Museo Argentino de Ciencias Naturales Bernardino Rivadavia, Ecologia 5:147-205.

Di Bitetti, M. S.; Di Blanco, Y. E.; Pereira, J. A.; Paviolo, A. \& Perez, I. J. 2009. Time partitioning favors the coexistence of sympatric Crab-eating Foxes (Cerdocyon thous) and Pampas Foxes (Lycalopex gymnocercus). Journal of Mammalogy 90(2):479-490.

EisenberG, J. F. 1999. Biodiversity Reconsidered. In: Eisenberg, J. F. \& Redford, K. H. eds. Mammals of the Neotropics: The Central Neotropics. Chicago, University of Chicago Press, p. 527-548.

Faria-Corrêa, M.; Balbueno, R. A.; Vieira, E. M. \& Freitas, T. R. O. 2009. Activity, habitat use, density, and reproductive biology of the crab-eating fox (Cerdocyon thous) and comparison with the pampas fox (Lycalopex gymnocercus) in a Restinga area in the southern Brazilian Atlantic Forest. Mammalian Biology 74(3):220-229. 
Flach, L.; Flach, P. A. \& Chiarello, A. 2008. Density, abundance and distribution of the guiana dolphin (Sotalia guianensis van Benéden, 1864) in Sepetiba Bay, Southeast Brazil. Journal of Cetacean Research and Management 10(1):31-36.

Fonseca, G. A. B.; Hermann, G. \& Leite, Y. L. R. 1999. Macrogeography of Brazilian Mammals. In: EIsEnBERG, J. F. \& Redford, K. H. eds. Mammals of the Neotropics: The Central Neotropics. Chicago, University of Chicago Press, p. 549-563.

Fontana, C. S.; Bencke, G. A. \& Reis, R. E. 2003. Livro Vermelho da Fauna Ameaçada de Extinção no Rio Grande do Sul. Porto Alegre, Edipucrs. 632p.

Gese, E. M. 2001. Monitoring of terrestrial carnivore populations. In: Gittleman, J. L.; FunK, S. M.; MacDonald, D. W. \& Wayne, R. K. eds. Carnivore Conservation. Cambridge, Cambridge University Press \& The Zoological Society of London, p. 372396.

GonzÁlez-Solís, J.; Guix, J. C.; Mateos, E. \& Lorens, L. 2001. Population density of primates in a large fragment of the Brazilian Atlantic rainforest. Biodiversity and Conservation 10(8):12671282.

Hoffmann, M. \& Sillero-Zubiri, C. 2004. Species Status Accounts. In: Sillero-Zubiri, C.; Hoffmann, M. \& MacDonald, D. W. eds. Canids: Foxes, Wolves, Jackals and Dogs. Status Survey and Conservation Action Plan. Gland, IUCN/SSC Canid Specialist Group, p. 21-80.

Kasper, C. B.; Soares, J. B. G. \& Freitas, T. R. O. 2012. Home range, use of shelters and movements patterns of Conepatus chinga (Mephitidae: Carnivora) in an agricultural landscape of southern Brazil. Mammalian Biology 77(5):358-362.

KinlaW, A. 1995. Spilogale putorius. Mammalian Species 511:1-7.

Maffei, L. \& Taber, A. B. 2003. Area de acción, actividad y uso de hábitat del zorro patas negras, Cerdocyon thous Linnaeus, 1776 (Carnivora: Canidae) en un bosque seco. Mastozoología Neotropical 10(2):154-160.

Medina, C. E.; Diaz, C. V.; Delgado, F. A.; Ynga, G. A. \& Zela, H. F. 2009. Dieta de Conepatus chinga (Carnivora: Mephitidae) em um bosque de Polylepis del departamento de Arequipa, Perú. Revista Peruana de Biologia 16:183-186.

Mourão, G. M.; Coutinho, M.; Mauro, R.; Campos, Z.; Tomas, W. M. \& MAgnusson, W. 2000. Aerial surveys of caiman, marsh deer and pampas deer in the Pantanal Wetland of Brazil. Biological Conservation 92(2): 175-183.

Overbeck, G. E.; Müller, S. C.; Fidelis, A.; Pfadenhauer, J.; Pillar, V. P.; Blanco, C. C.; Boldrini, I. I.; Both, R. \& Forneck, E. D. 2009. Os Campos Sulinos: um bioma negligenciado. In: PILlar,
V. P.; Müller, S. C.; Castilhos, Z. M. S. \& Jacques, A. V. A. eds. Campos Sulinos: Conservação e Uso Sustentável da Biodiversidade. Brasília, Ministério do Maio Ambiente, p. 26-41.

PANeK, M. 2009. Factors affecting predation of red foxes Vulpes vulpes on brown hares Lepus europaeus during the breeding season in Poland. Wildlife Biology 15(3):345-349.

Peres, C. 1997. Primate community structure at twenty western Amazonian flooded and unflooded forests. Journal of Tropical Ecology 13(3):381-405.

Peters, F. B.; Roth, P. R. O. \& Christoff, A. U. 2011. Feeding habits of Molina's hog-nosed skunk, Conepatus chinga (Carnivora: Mustelidae) in the extreme south of Brazil. Zoologia 28(2):193-198.

Pia, M. V.; Lopez, M. S. \& Novaro, A. J. 2003. Effects of livestock on the feeding ecology of endemic culpeo foxes (Pseudalopex culpaeus smithersi) in central Argentina. Revista Chilena de Historia Natural 76(2):313-321.

Pillar, V. P.; Müller, S. C.; Castilhos, Z. M. S. \& Jacques, A. V. A. 2009. Campos Sulinos: Conservação e Uso Sustentável da Biodiversidade. Brasília, Ministério do Meio Ambiente. 403p.

PindER, L. 1997. Estimativa da população de cervos-do-pantanal no Rio Paraná utilizando levantamento aéreo. In: ValladARES-PAduA, C. \& Bodmer, R. E. eds. Manejo e Conservação de Vida Silvestre no Brasil. Belém, Sociedade Civil Mamirauá, p. 116-122.

Reppucci, J. I.; Castillo, D. F.; Lucherini, M.; Vidal, E. M. L. \& CASANAVE, E. B. 2009. Interindividual interactions of Molina's hog-nosed skunks Conepatus chinga in the Pampas grassland of Argentina. Acta Theriologica 54(1):87-94.

Rocha, E. C.; Silva, E.; Feio, R. N.; Martins, S. V. \& Lessa, G. 2008. Densidade populacional de raposa-do-campo Lycalopex vetulus (Carnivora, Canidae) em áreas de pastagem e campo sujo, Campinápolis, Mato Grosso, Brasil. Iheringia, Série Zoologia 98(1):78-83.

Santana, B. E. M. M.; Prado, M. R. P.; Lessa, G.; Rocha, E. C. \& Melo, F. R. 2008. Densidade, tamanho populacional e abundância dos primatas em um fragmento de Floresta Atlântica em Minas Gerais, Brasil. Revista Árvore 32(6):1109-1117.

Schaller, G. B. \& Vasconcelos, J. M. 1978. A marsh deer census in Brazil. Oryx 14(4):345-351.

Thomas, L.; Buckland, S. T.; Rexstad, E. A.; Laake, J. L.; Strindberg, S.; Hedley, S. L.; Bishop, J. R. B.; Marques, T. A. \& Burnham, K. P. 2010. Distance software: design and analysis of distance sampling surveys for estimating population size. Journal of Applied Ecology 47(1):5-14.

Wade-Smith, J. \& Verts, B. J. 1982. Mephitis mephitis. Mammalian Species 173:1-7.

Recebido em 28 de fevereiro de 2012. Aceito em 13 de setembro de 2012. ISSN 0073-4721

Artigo disponível em: www.scielo.br/isz 